\title{
Mg isotopic fractionation involving magmatic-hydrothermal transition recorded in the Himalayan granites
}

DONG-YONG LI ${ }^{12 *}$, FANG-ZHEN TENG ${ }^{2}$, YILIN XIAO ${ }^{1}$, ZHI- $^{5}$ CHAO LIU ${ }^{3}$, HAI-OU GU ${ }^{4}$, WANG-YE LI ${ }^{1}$, FU-YUAN WU ${ }^{5}$

${ }^{1}$ University of Science and Technology of China, Hefei, China

${ }^{2}$ University of Washington, Seattle, WA, USA

${ }^{3}$ Sun Yat-sen University, Guangzhou 510275, China

${ }^{4}$ Hefei University of Technology, Hefei, China

${ }^{5}$ Institute of Geology and Geophysics, CAS, Beijing, China (*Correspondence author: 1dy@ustc.edu.cn)

Fluids can not only make a substantial contribution to pegmatite deposits but also play an important role in the magmatic differentiation of granitic melts. Whether or not stable isotopes fractionate during the evolution of granitic magma involving fluidmelt interaction remains unclear. $\mathrm{Mg}$ isotopic compositions of Himalayan leucogranites, including two-mica leucogranites and muscovite leucogranites, were carried out in this study, and the results display that muscovite leucogranites have lower $\delta^{26} \mathrm{Mg}$ values than two-mica leucogranites. The positive or negative relations are observed between $\delta^{26} \mathrm{Mg}$ values and other geochemical makers for magmatic-hydrothermal transition, indicating $\mathrm{Mg}$ isotopes fractionate during the magmatic evolution involving fluids. Our modellings of Rayleigh fractionation equation demonstrate that the $\mathrm{Mg}$ isotopic variations of Himalayan granites in this study is the consequence of magmatic-hydrothermal transition. Thus we speculate that muscovite leucogranites are formed from more evolved felsic than two-mica leucogranites, excluding the possibility of heterogeneous rocks or different melting reactions. Furthermore, the ubiquitous fluids during late stage of evolution of granites imply that the Himalayan leucogranites have significant potential for pegmatite deposits, especially the LCT-family pegmatite deposits.

This work was financially supported by grants from the National Natural Science Foundation of China (41729001). 